\title{
健全な水循環の維持・回復に向けた地下水マネジメント
}

\author{
林 里香*

\section{Groundwater management to the maintenance and recovery of healthy water cycle}

\author{
Rika HAYASHI*
}

\section{1. はじめに}

水は古くから利用され人が生きていく上で欠か すことのできない限りある資源であり，循環する 過程で動植物の生息環境の保全や国民生活, 産業 活動に重要な役割を果たし，産業や文化を育んで きた。地下水はこの水循環を構成する重要な要素 であり, 工業用水, 農業用水, 生活用水をはじ め，まちづくりや地域観光にも利用されてきた。

また平成26年に制定された水循環基本法に基づ き, 平成27年に閣議決定された水循環基本計画に おいては, 課題についての共通認識の醸成や, 地 下水の利用や挙動の実態把握とその分析・可視 化, 保全 (質・量), 涵養, 採取等に関する地域 における合意やその内容を実施するマネジメント を「地下水マネジメント」というとされている。 この地下水マネジメントは, 地方公共団体など地 域の関係者が主体となり取り組むものとされ，国 は地方公共団体等の地域における主体的な取組を 支援する役割を担うとされている。

こうした状況を踏まえ, 環境省では, 国民共有
の貴重な財産である地下水を保全するため, 地下 水質と地下水量の保全対策を進めている。

\section{2. 地下水質の保全対策}

\section{1 水質污濁防止法による地下水質保全対策}

地下水污染は, 原因者の特定が難しいことに 加え, 一度污染されると回復が困難であることか ら, 污染を未然に防止することが非常に重要であ る。

昭和45年に制定された水質污濁防止法に基づ き, 地下水の水質污濁の常時監視, 有害物質を含 む水の地下浸透規制, 事故時の措置, 污染された 地下水の浄化等の措置が講じられてきたが, 平成 23年の同法の改正により, 届出義務の対象となる 施設の拡大，施設の構造等に関する基準の遵守義 務，定期点検の実施義務等に関する規定が設けら れた。このような地下水污染の未然防止等の対策 を，地方公共団体と連携して推進している。また 平成26年 9 月に中央環境審議会より，地下浸透基 準の設定方法の妥当性について検証が必要である

*当時：環境省 水・大気環境局 土壤環境課地下水・地盤環境室 室長補佐（广100-8975 東京都千代田区霞ヶ関1-2-2）

(現：環境省大臣官房総務課 環境情報室長 \& 危機管理室長)

* Then: Office of Groundwater and Ground Environment, Environmental Management Bureau, Ministry of the Environment Deputy Director

(Present: Office of Environmental information technology \& Office of Crisis Management, General Affairs Division, Minister's Secretariat, Ministry of the Environment Director) 
との答申が出されたことを受け, 平成27年度から 地下浸透規制のあり方についての検討を進めてい る。

\section{2 地下水質の現状と課題}

環境省では, 全国の地方公共団体が実施した常 時監視により把握した地下水質の状況について一 元的にとりまとめ, 毎年公表している。平成27年 度の概況調査の結果については, 全体の地下水環 境基準の超過率は $5.8 \%$, 最も超過率の高い項目 は硝酸性窒素及び亜硝酸性窒素（以下，硝酸性窒 素等という) であり $3.5 \%$ であった。また継続監 視調査の結果については, 硝酸性窒素等による污 染が確認された超過井戸の本数が最も多く, 改善 がなかなか進んでいない状況である。地域によっ ては広域的な地下水污染が継続して認められるこ とから，その対策が急務な状況である。硝酸性窒 素等による地下水污染の原因は, 過剩な施肥, 家 畜排せつ物や生活排水の不適切な処理等にあり, その供給源は面的かつ多岐にわたることから，水 質污濁防止法による点源規制のみでは対応が難し いため, 流域の関係者が一体となって, 地域の実 情に応じた最適な施策を組み合わせた総合的な対 策を推進する必要がある。

環境省としては, 地域における硝酸性窒素等に よる地下水污染対策を推進するため, これまでマ ニュアル，指針，事例集等を策定してきている。 先に述べた, 水循環基本計画に基づく地下水マネ ジメントの推進が求められる状況を踏まえ, 過去
に策定したマニュアルや指針等について新たな知 見・情報等を追加して, 構成等を再編集し, 技術 的なマニュアルの策定を行い，平成28年 5 月に公 表した。

\section{3 地下水質対策の今後の方向性}

平成27年度から硝酸性窒素等に係る地域の取組 を推進するための支援を開始し，平成28年度から は，地域の関係者間の合意形成を図るために活用 することを目的とした地下水質シミュレーション モデルの構築に向けた検討に着手した。そして, 将来的には, 以上の支援の状況も含めて, 地域に おける取組を推進するために必要となる硝酸性窒 素等対策ガイドラインを作成する予定である。

\section{3. 地下水量の保全対策}

\section{1 地盤沈下の現況}

昭和30年代の高度経済成長期の過剰な地下水採 取により地盤沈下が問題となり, 昭和31年に工業 用水法及びビル用水法を制定し地下水採取規制を 実施してきた。また地盤沈下防止の観点から, 関 係閣僚会議で決定した「地盤沈下防止等対策要 綱」）に基づき 3 地域（濃尾平野，筑後・佐賀平 野及び関東平野北部）の地盤沈下防止対策を関係 府省で実施するとともに，地方公共団体において は，地下水採取の規制に関する条例を制定し，規 制・監視を継続的に実施している。

地域の実情に応じた総合的な対策等により，高

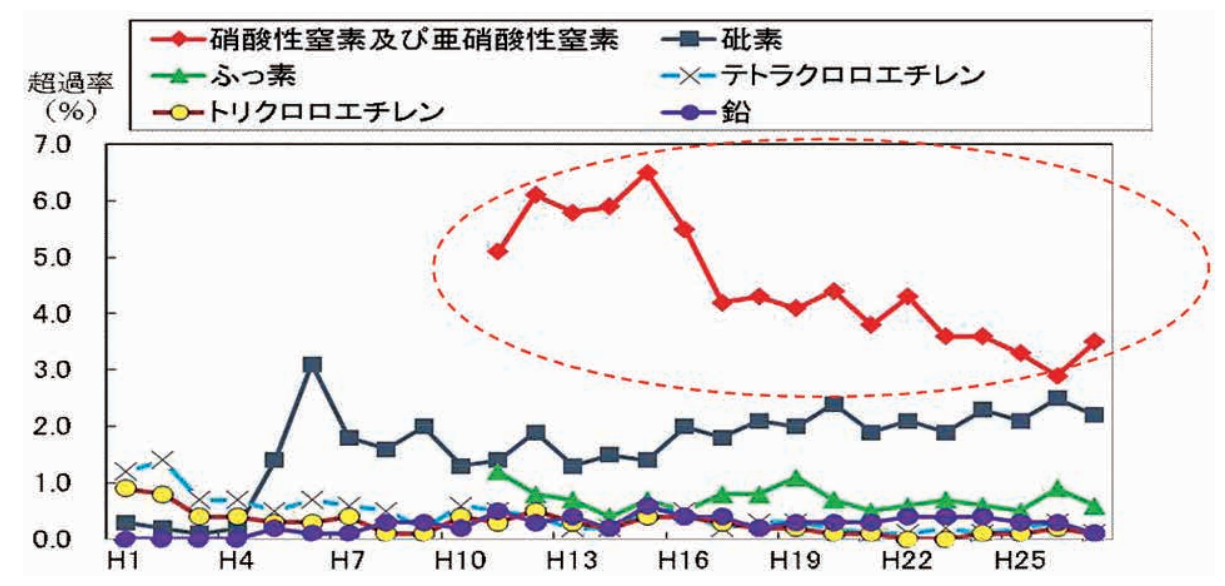

図 1 水質污濁防止法第 15 条による常時監視の結果【概況調查】（環境省水・大気環境局，2016a） 
度経済成長期以前から地盤沈下が著しかった地域 においては，地盤沈下は沈静化の傾向がある。一 方, 今なお沈下が進行している地域もあり, 一層 の対策が求められる。

環境省では, 全国の地方公共団体が調査・確認 した地盤沈下の状況について一元的にとりまと め, 毎年公表している。平成23～27年度に地盤沈 下が認められた地域は36地域あり，なかでも平成
27 年度には, 千葉県八街市で最大 $2.51 \mathrm{~cm}$, 千葉 県茂原市で最大 $2.41 \mathrm{~cm}$, 石川県金沢市で最大 2.51 $\mathrm{cm}$, 新潟県南魚沼市で最大 $2.21 \mathrm{~cm}$ の地盤沈下が 確認された。これらは天然ガスの採取や冬期の融 雪利用など，特定の用途のために地下水が採取さ れていることに起因するものと考えられる。

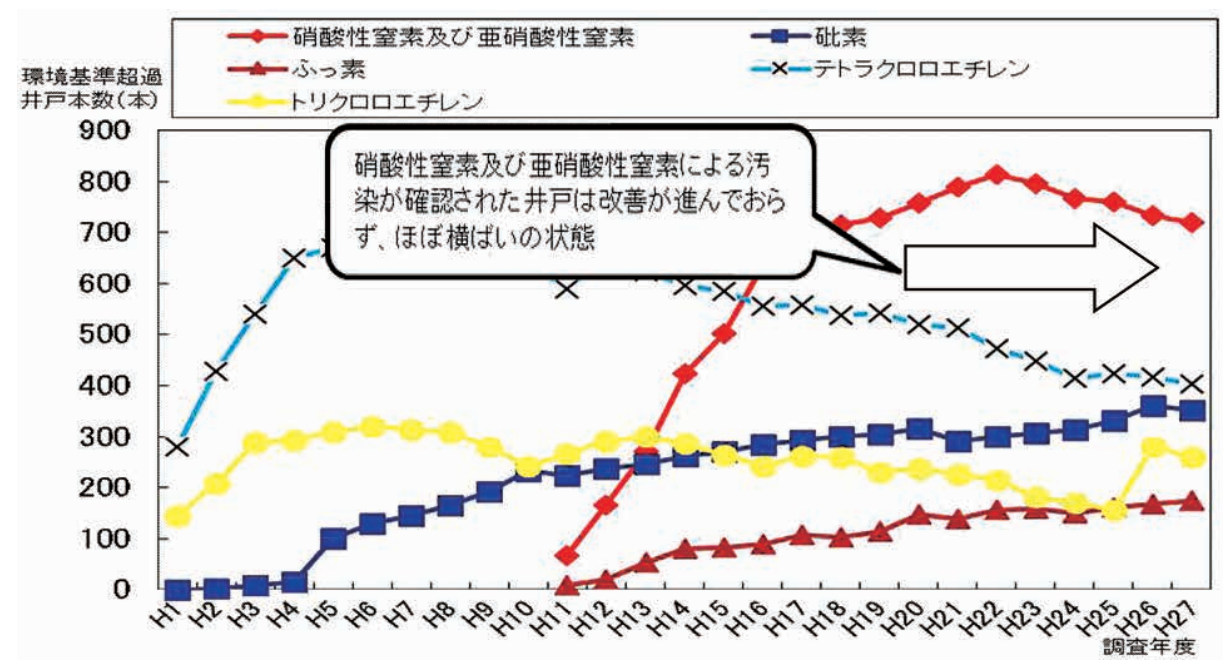

図 2 水質污濁防止法第 15 条による常時監視の結果【継続監視調査】(環境省水・大気環境局, 2016a)

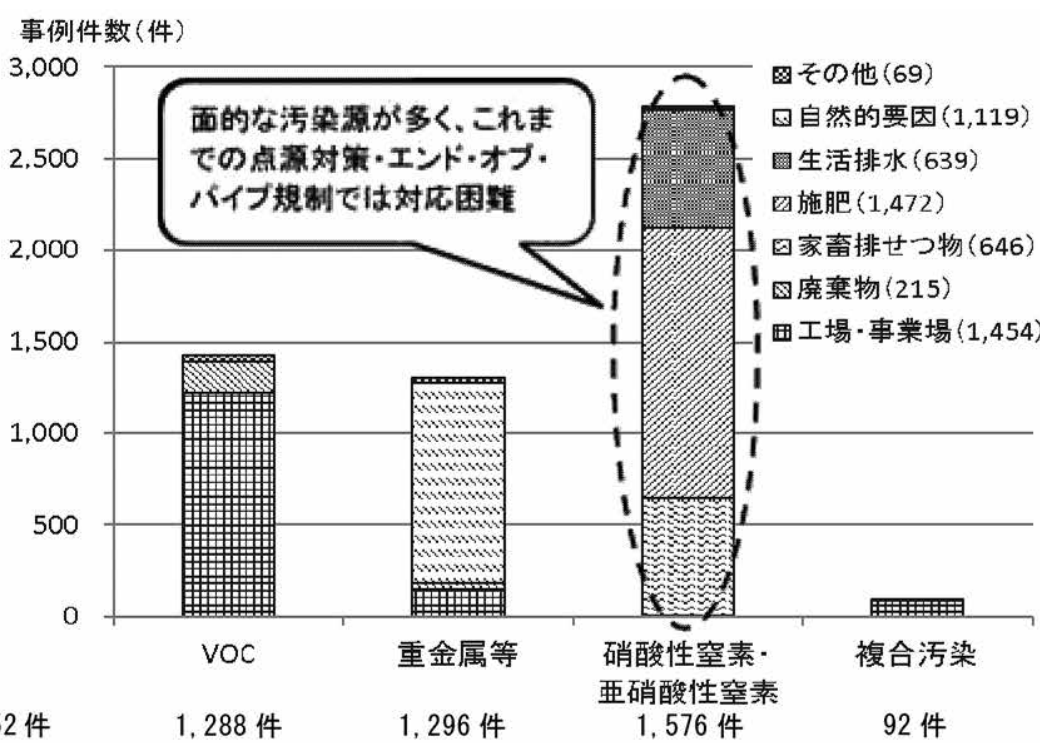

合計 4,252 件

1,288 件

1,576 件

92 件

※複数の污染原因による事例があるため、グラフの合計值と事例件数は必ずしも一致しない。

図 3 地下水污染の污染原因別件数【平成 27 年度】(環境省水・大気環境局, 2016a) 


\section{2 地盤沈下に係る現状と課題}

地下水を取り巻く環境は時代の変遷とともに恋 化してきている。かつて高度経済成長期に深刻 であった地下水の過剩採取による広域の地盤沈 下は，地下水採取規制等の効果で地下水位が回 復・上昇したことから全体的には沈静化しつつあ るが, 現在も一部地域で継続し, 引き続き地下水 採取規制, 代替水源の確保等による対策が行われ ている。一方で，かつては広域の地盤沈下が深刻 であった大都市地域では地下水採取規制等により 地下水位が回復・上昇するなど, 地下水を取り巻 く環境に新たな変化が見られる。さらに, ヒート アイランド対策や再生可能エネルギーとしての利 用，防災利用など多面的な利用が広がっている状 況の中で, 広域の地盤沈下を防止しつつ, 地下水 の有効利用を図る方策の確立が求められている。

\section{3 「地下水保全」ガイドライン〜地下水保全 と持続可能な地下水利用のために〜}

このような中, 環境省では, 地方公共団体の環 境部局等が地下水・地盤環境の保全などの関連施 策を円滑に進めるための指針として，『「地下水保 全」ガイドライン〜地下水保全と持続可能な地 下水利用のために〜』(環境省水・大気環境局, 2016c）を公表した。

本ガイドラインは, 地下水をめぐる最近の動向 と地下水保全に向けた技術的, 法・制度的課題, 地下水保全のあるべき基本的な考え方を整理し, 地下水の適切な保全管理のための方策をとりまと めたものである。また，地下水保全に関して先進 的な地域の取組事例を紹介している『「地下水保 全」事例集～地下水保全と持続可能な地下水利用 のために〜』（環境省水・大気環境局, 2016c) も 併せて公表している。

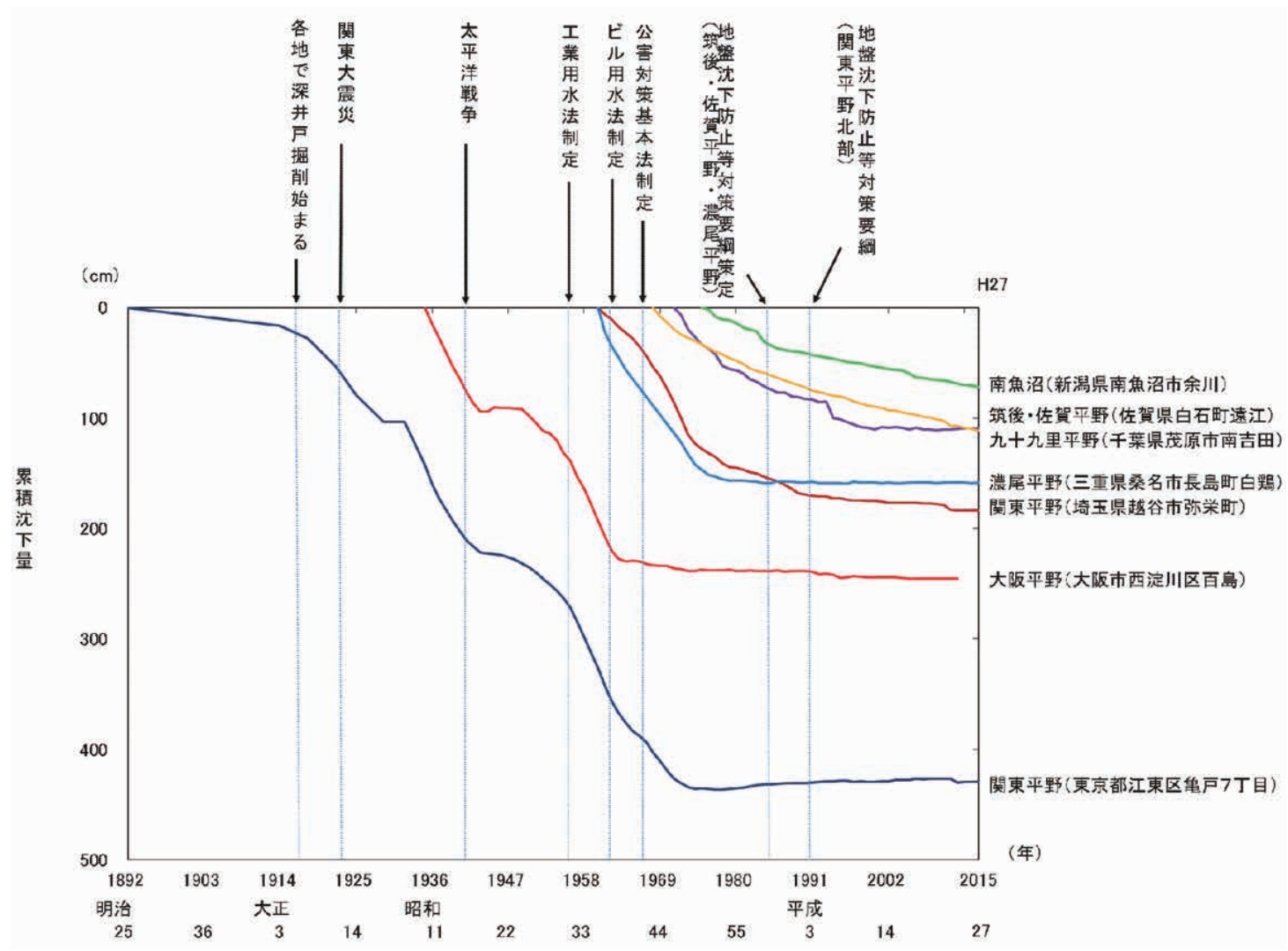

図 4 代表的地域の地盤沈下の経年変化（環境省水・大気環境局, 2016b) 


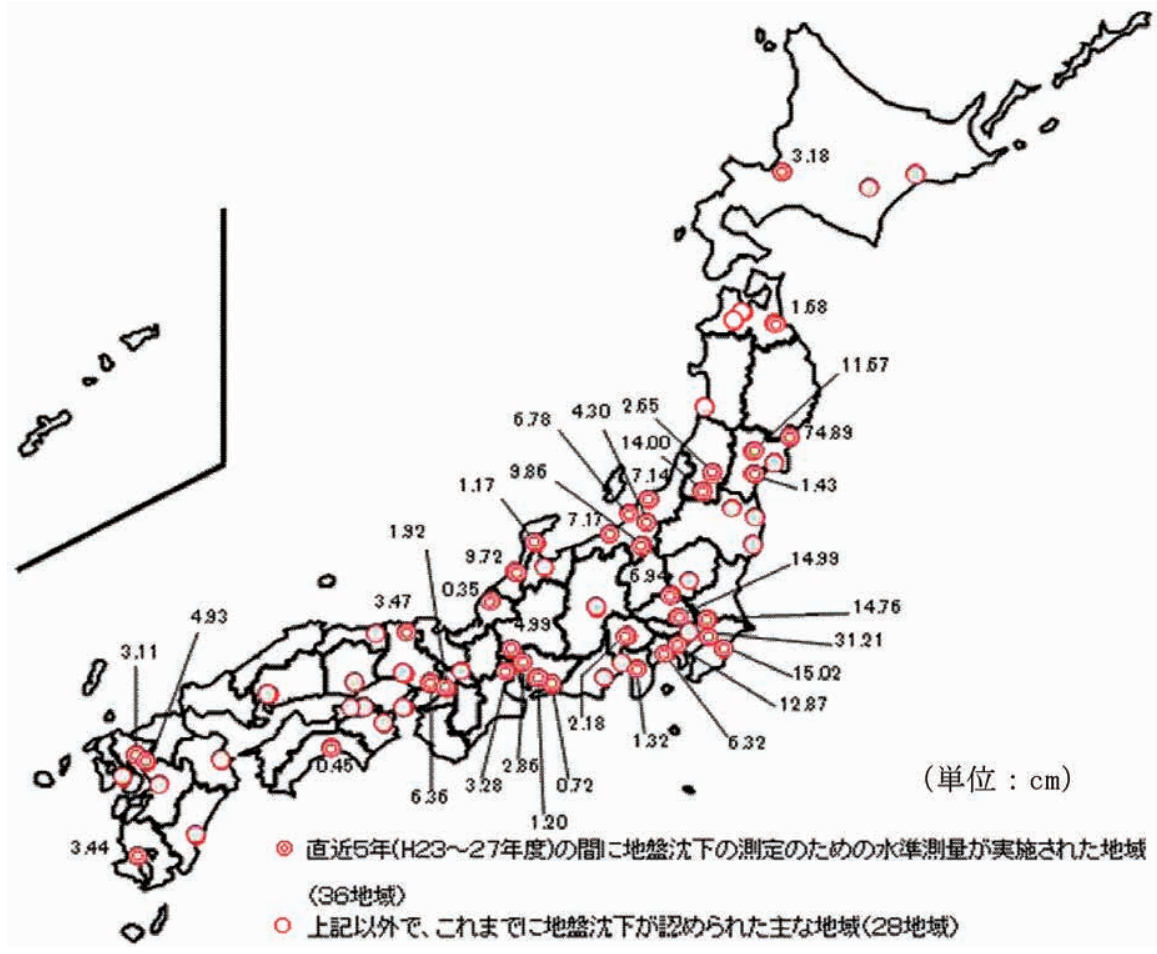

図 5 平成 $23 \sim 27$ 年度の累積沈下量（環境省水・大気環境局, 2016b)

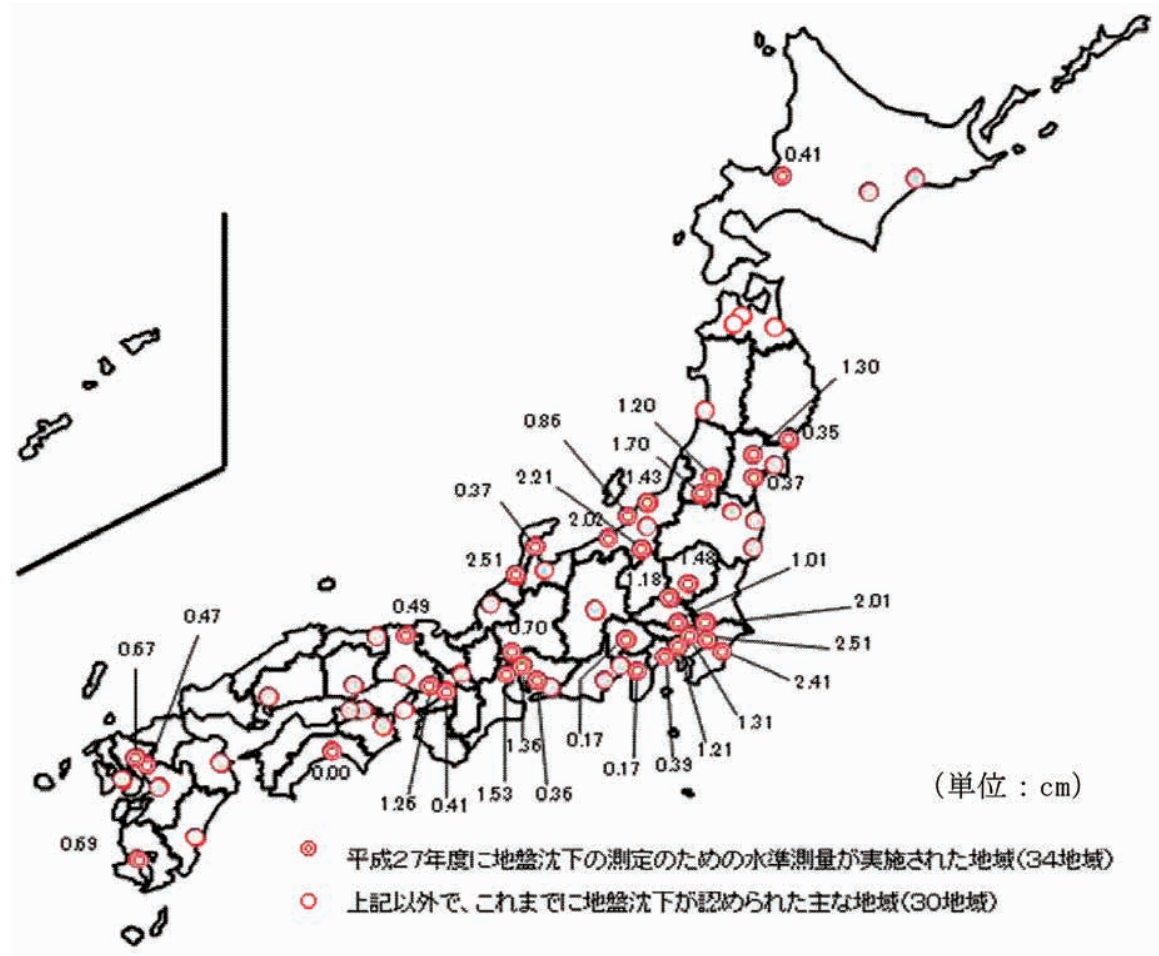

図 6 平成 27 年度の地盤沈下観測状況（環境省水・大気環境局, 2016b） 


\section{4 地下水採取規制の適正化に向けた検討}

平成28年 5 月に定められた防災基本計画では, 地盤沈下防止を通じた風水害に強い国土形成の実 施が謳われており, 想定される津波や高潮等の減 災に向け, 沿岸部の各地域では, 早急に地盤沈下 の抑止対策を講じる必要がある。一方, 地球温暖 化対策の推進に関する法律に基づき，平成28年 5 月に定められた地球温暖化対策計画において, 再 生可能エネルギー熱の一つとして, 地中熱利用の 最大限の導入が求められている。また, 豪雪地帯 では冬期の融雪用に地下水が利用され，これによ り地盤沈下が進行している地域がある。

これらのことに鑑み, 不可逆的な公害である地 盤沈下を防止しつつ, 地下水を貴重な水資源とし て有効利用できるよう, 定量的な根拠に基づた 地下水採取規制の適正化が喫緊の課題となってい る。環境省では, 地下水採取量や地盤沈下量等の 経年データを適切に管理しつつ, 地下水の実態に 基づいた地下水マネジメントが実施できるような 仕組みの実現をめざして, 地下水採取規制のあり 方の検討を進めている。

\section{4. おわりに}

環境省では，国民共有の貴重な財産である地下 水を保全するため, 地下水の挙動を把握しつつ, 地下水質と地下水量の保全対策を一体的に進めて いくことにより, 地域に扮ける適正な地下水マネ ジメントの実現をめざして, 地方公共団体や国等 の関係者と密接に連携した取組を, 引き続き進め ていく予定である。

\section{参考文献}

環境省水 ·大気環境局 (2016a) : 平成27年度地下水質 測定結果 http://www.env.go.jp/water/report/h2803/index.html（2017.6.13閲覧）

環境省水 ·大気環境局 (2016b)：平成27年度全国の

地盤沈下地域の概況 http://www.env.go.jp/water/ jiban/chinka.html（2017.6.13閲覧）

環境省水・大気環境局 (2016c)：「地下水保全」ガイド ライン〜地下水保全と持続可能な地下水利用のため

に〜 http://www.env.go.jp/water/jiban/guide.html (2017.6.13閲覧)

(受付：2017年 6 月 13 日, 受理：2017年 9 月 12 日) 